\title{
CNS toxoplasmosis in acquired immune deficiency syndrome: a clinical-pathological-radiological review of 12 cases
}

\author{
ARTHUR E FARKASH, PAUL J MACCABEE, JOANNA H SHER, \\ SHELDON H LANDESMAN, GWENDOLYN HOTSON
}

From the Department of Neurology, State University of New York, New York, USA

SUMMARY From January 1981 to January 1983 acquired immune deficiency syndrome (AIDS) was diagnosed in 90 patients admitted to Kings County Hospital-Downstate Medical Center. CNS involvement occurred in 18 patients of whom 12 had toxoplasmosis confirmed by biopsy or necropsy. Pathological specimens from these 12 patients were notable for a marked diminution or absence of cellular inflammation. Each patient had elevated serological studies for toxoplasma. AIDS presented with symptoms referable to CNS toxoplasma in eight patients. In the remaining four patients, toxoplasma was found late in the course of the illness. CT showed either ring enhancing lesions or solid nodules. The course was uniformly fatal, though patients treated continuously with pyrimethamine and sulfadiazine survived longer.

The acquired immune deficiency syndrome (AIDS) is defined as a defect in cell-mediated immunity occurring in previously healthy individuals which is associated with multiple opportunistic infections with or without Kaposi's sarcoma. ${ }^{1}$ A subgroup of these patients have secondary and life threatening CNS toxoplasmosis. ${ }^{2}$ Between January 1981 and January 1983, 90 AIDS patients were diagnosed at Kings County Hospital-Downstate Medical Center (KCH-DMC). Eighteen of these patients had CNS involvement. This report summarises the clinical, pathological and radiographic features of 12 of these 18 patients who had CNS toxoplasmosis.

\section{Patients and methods}

Of these 12 patients, six were Haitian, three IV drug abusers, one a Haitian homosexual, one homosexual and one patient belonged to no known risk group. All 12 patients fulfilled the criteria for AIDS established by the Center for Disease Control. ${ }^{3}$ Despite careful investigation, the Haitian patients failed to meet criteria for any risk group. CNS involvement was documented by neurological examination, post-contrast CT scan, serum and CSF studies including Sabin-Feldman

Address for reprint requests: Paul J Maccabee, M.D. Department of Neurology, Box 35, State University of New York, Downstate Medical Center, 450 Clarkson Avenue, Brooklyn, New York 11203, USA

Received 9 April 1985 and in revised form 24 October 1985. Accepted 2 November 1985
Dye Test, immunofluorescent antibody (IFA), toxoelisa titre, and by identification of trophozoites on biopsy or necropsy specimens of brain tissue.

\section{Clinical and laboratory findings}

Medical complications including opportunistic and nonopportunistic infections outside the CNS are listed in table 1. Signs and symptoms of neurological involvement occurred before (six patients, nos 1, 2, 3, 6, 10, 12 table 2), concomitant with (two patients, nos 7, 8 table 2), or after (four patients, nos 4, 5, 9, 11 table 2) systemic manifestations. Serologic studies for toxoplasma were positive in all of 9 patients. In two patients who had recurrence of toxoplasma, titres remained elevated. Serum Sabin-Feldman dye titres of $>1: 6400$ (normal <1:100) were present in all three patients in whom this test was performed, and CSF titres were elevated in two of these three patients (table 3). Enzymelinked immunoabsorbent assay for Toxoplasma gondii antibody in human serum (toxo-elisa) studies were abnormal in all seven patients in whom this test was performed, but were negative in two CSF examinations performed in four of these patients. Serum immunofluorescent antibody (IFA) was abnormal in all six patients and CSF IFA was abnormal in two of four patients in whom these tests were performed.

CT revealed discrete lesions in 11 patients and two or more lesions were present in eight. Twenty of these lesions were ring enhancing and 12 were solid. The most frequent locations were within or adjacent to the cortical gray-white matter interface (19 lesions). Five lesions were present in basal ganglia and two in cerebellum. In one patient, multiple calcified lesions and nonenhancing hypodense areas were present in both hemispheres, and diffuse gyral enhancement was also demonstrated. 
CNS toxoplasmosis in acquired immune deficiency syndrome

Table 1 Summary of patients with risk groups, age, underlying infections and medical complications

\begin{tabular}{|c|c|c|c|c|c|c|}
\hline Patient No & Background & $\begin{array}{l}\text { Age } \\
(y r)\end{array}$ & Months in $U$ & Other opportunistic infections & Other systemic infections & Other medical complications \\
\hline $\begin{array}{l}1 \\
2 \\
3 \\
4 \\
5\end{array}$ & $\begin{array}{l}\text { Haitian } \\
\text { Haitian } \\
\text { Haitian } \\
\text { Haitian Homosex } \\
\text { IV drug abuser }\end{array}$ & $\begin{array}{l}29 \\
29 \\
27 \\
32 \\
29\end{array}$ & $\begin{array}{l}24 \\
10 \\
12 \\
?\end{array}$ & $\begin{array}{l}\text { GI candidiasis } \\
\text { GI candidiasis } \\
\text { GI candidiasis Kaposi's sarcoma } \\
\text { GI candidiasis H simplex } \\
\text { GI candidiasis PCP† }\end{array}$ & \multirow{3}{*}{$\begin{array}{l}\text { Tuberculosis* } \\
\text { Tuberculosis* } \\
\text { E coli sepsis } \\
P \text { aeruginosa } \\
\text { S aureus meningitis } \\
\text { Klebsiella sepsis } \\
\text { Syphilis* Gonorrhoea* } \\
\text { GI tuberculosis } \\
\text { E coli sepsis Shigellosis }\end{array}$} & \multirow{3}{*}{$\begin{array}{l}\text { Renal failure } \\
\text { SIADH } \$ \\
\text { Pericarditis } \\
\text { Diabetes mellitus } \\
\text { SIADH } \\
\text { SIADH } \$\end{array}$} \\
\hline & None & 42 & 144 & PCP+ & & \\
\hline $\begin{array}{r}7 \\
-8 \\
9 \\
10 \\
11 \\
12\end{array}$ & $\begin{array}{l}\text { Homosex } \\
\text { Haitian } \\
\text { Haitian } \\
\text { IV drug abuser } \\
\text { Haitian } \\
\text { IV drug abuser }\end{array}$ & $\begin{array}{l}51 \\
27 \\
25 \\
35 \\
27 \\
37\end{array}$ & ${ }^{/} 24$ & $\begin{array}{l}\text { GI candidiasis Kaposi's sarcoma } \\
\text { GI candidiasis PCP† } \\
\text { PCP }+ \text { GI candidiasis } \\
\text { GI candidiasis }\end{array}$ & & \\
\hline
\end{tabular}

GI = gastrointestinal tract.

* Occurred prior to diagnosis of AIDS.

+Pneumocystis Carinii Pneumonia.

ISyndrome of inappropriate secretion of antidiuretic hormone.

Table 2 Clinical presentation of AIDS

\begin{tabular}{|c|c|c|c|}
\hline \multirow{2}{*}{$\begin{array}{l}\text { As a neurological disease alone or with systemic } \\
\text { illness }\end{array}$} & \multicolumn{3}{|l|}{ As a systemic illness } \\
\hline & Systemic presentation & Interval & Neurological presentation \\
\hline $\begin{array}{l}\text { Right facial paresis, absent right corneal reflex, } \\
\text { right focal seizures } \\
\text { Painful, paretic right upper extremity } \\
\text { Right facial palsy, right upper extremity } \\
\text { paresis, right focal seizures with generalisation }\end{array}$ & $\begin{array}{l}\text { No } 4 \text { H simplex proctitis Oral } \\
\text { candidida, weight loss } \\
\text { No } 5 \text { Dysphagia, weight loss } \\
\text { No } 9 \text { Fever, diarrhoea } \\
\text { n }\end{array}$ & $\begin{array}{l}2 \mathrm{mos} \\
5 \mathrm{mos} \\
41 / 2 \mathrm{mos}\end{array}$ & $\begin{array}{l}\text { Sudden onset confusion } \\
\text { Lethargy, headache, generalised seizures } \\
\text { Right focal seizures, generalised } \\
\text { seizures lethargy }\end{array}$ \\
\hline $\begin{array}{l}\text { Lethargy, nystagmus } \\
\text { Headache, fever, weight loss } \\
\text { Lethargy, inappropriate behaviour, fever, } \\
\text { weight loss } \\
\text { Left hemiparesis } \\
\text { Ptosis left eye, dilated left pupil, lethargy }\end{array}$ & No 11 Fever, weight loss & $3 \mathrm{mos}$ & Lethargy, rapidly progressing to stupor \\
\hline
\end{tabular}

Table 3 Summary of laboratory findings

\begin{tabular}{llllll}
\hline Patient no & Toxoelisa* & Serum Sabin-Feldman & IFA & Toxolisa & \multicolumn{1}{l}{ CSF Sabin-Feldman IFA } \\
\hline 1 & 1.50 & $>1: 6400$ & $1: 1024$ & 0.33 & $1: 75$ \\
2 & $1.15 \dagger$ & $1: 6400$ & $1: 256$ & 0.17 & $1: 512$ \\
3 & 1.19 & & & 0.84 & \\
4 & $1.43 \dagger$ & & & & \\
7 & 1.53 & $>1: 6400$ & & & \\
8 & 1.27 & & $1: 256$ & & $>1: 16$ \\
10 & 1.20 & 1.17 & $1: 1024$ & 1.09 & \\
11 & 1.30 & & $1: 256$ & & \\
12 & & $1: 128$ & & negative \\
\hline
\end{tabular}

"Enzyme-linked immunoabsorbent assay for $T$ gondii IgG antibody in human serum. $>0.21$ positive for prior exposure, 0.18-20 equivocal. $<0.18$ absence of prior exposure. trepresents different hospital admissions.

Pathological findings

Fragments of tissue removed surgically from eight patients showed gross evidence of pale yellow opaque coagulation necrosis. Microscopically, this necrosis was present in all but one case, and contained outlines of blood vessels with markedly thickened walls, as well as nuclear fragments. Cellular reaction surrounding the necrosis varied. In more acute cases, many polymorphonuclear leucocytes were present, along with a few histiocytes and plasma cells. Other lesions showed few polymorphonuclear leucocytes and numerous histiocytes and plasma cells. Relatively large lymphocytes were present in all cases. Little fibrosis was present in most sections, but in a few there was a thin fibrous capsule. Vasculitis was prominent in all lesions. The small veins, arterioles, and venules at the edges of the necrosis revealed invasion of their walls by polymorphonuclear leucocytes, plasma cells, and large lymphocytes. Many vessels with markedly thickened fibrotic walls were noted, and a few inflamed vessels close to necrotic regions also showed thrombosis (fig 1).

Numerous cysts containing characteristic $2-4 \mu \mathrm{m}$ basophilic toxoplasma organisms were seen and groups of trophozoite were frequently observed in tissue sections (fig 2). 


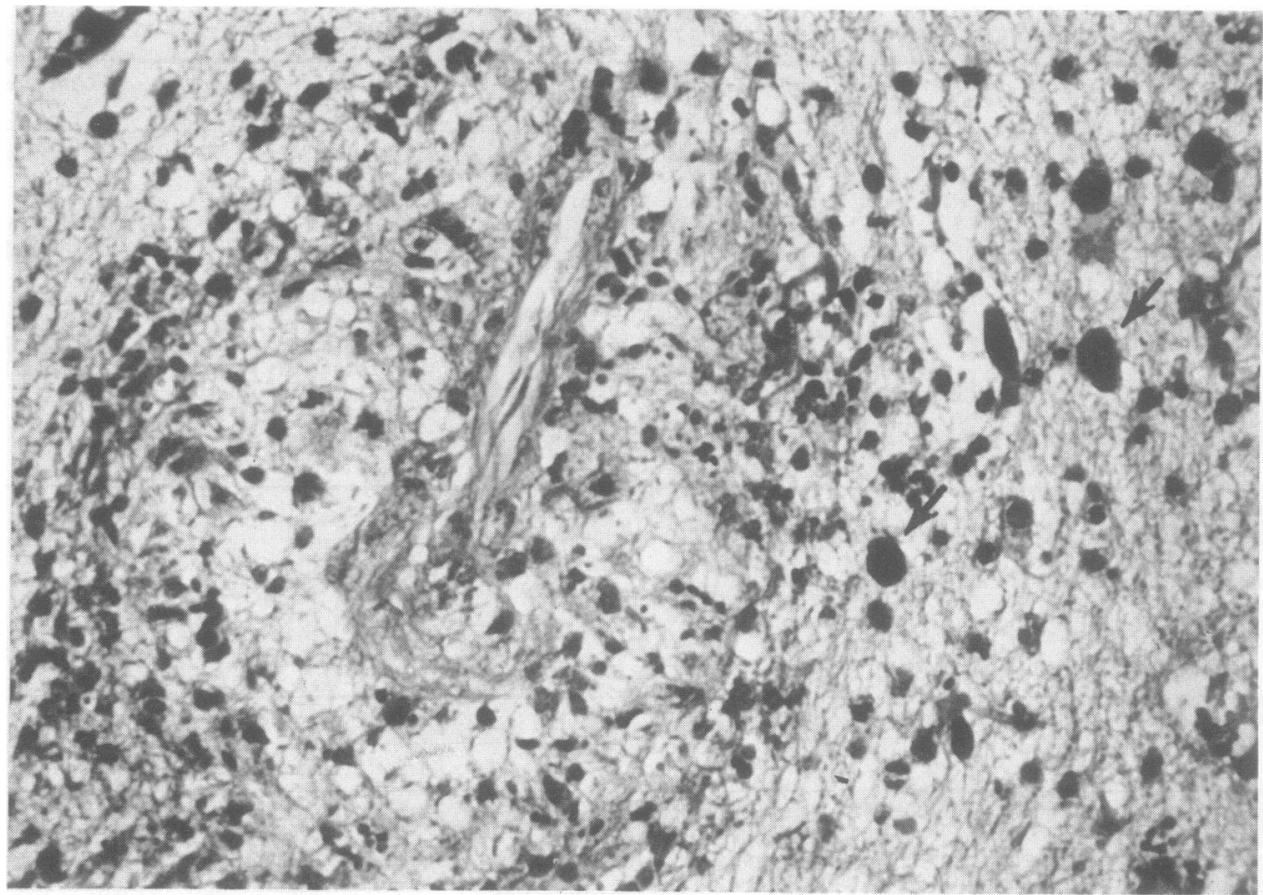

Fig 1 Area at edge of toxoplasma granuloma showing vasculitis, scanty inflammatory infiltrate, and several large cysts containing toxoplasma organisms (arrows) ( $H$ and $E, \times 280$ ) (Case 5).

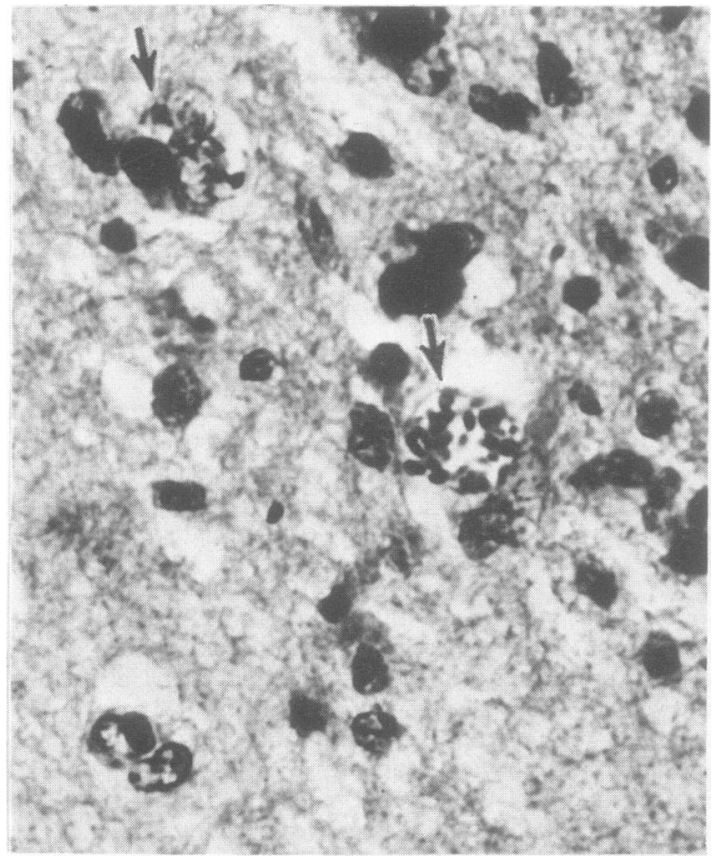

Fig 2 Cysts containing toxoplasma organisms in white matter (arrows). ( $H$ and $E, \times 660$ ) (Case 3).

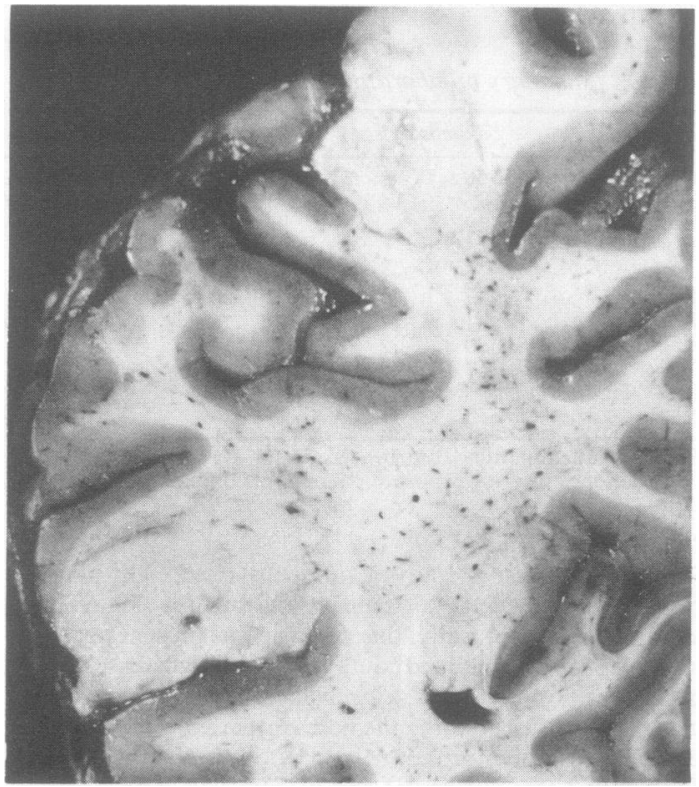

Fig 3 Macroscopic photograph of necrotising toxoplasma granulomas in coronal section of occipital lobe (Case 5). 


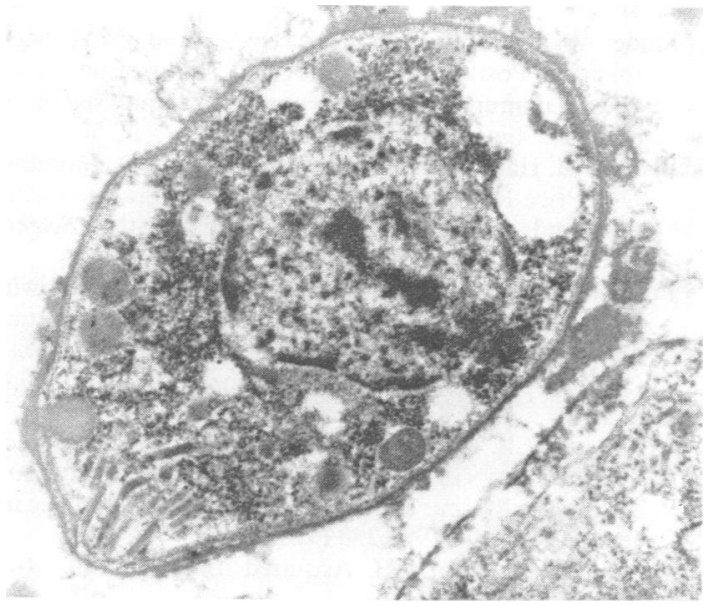

Fig 4 Electron micrograph of toxoplasma organism showing central nucleus, and conoid at lower left. ( $\times 11,900)$ (Case 5).

These organisms were found within the inflammatory reaction surrounding necrotic areas. Outside the inflamed area, cerebral tissue demonstrated moderate macrophage and reactive astrocytic proliferation.

Four cases of cerebral toxoplasmosis came to necropsy. In three, there were $2-4 \mathrm{~cm}$ necrotising granulomas, with very thin capsules and scanty inflammatory response (fig 3 ). Toxoplasma organisms in cysts were present in areas of inflammation. Two cases demonstrated confluent cystic lesions, as well as necrotic masses. In one case, granulomas were not found, but there was an area of vasculitis in cerebellar white matter, with toxoplasma organisms in adjacent tissue.

Electron microscopic examination of surgical specimens showed typical toxoplasma organisms. These were characterised by double membranes, centrally placed nuclei, and conoid structures with rhophtries (fig 4).

\section{Clinical course}

The clinical course in all 12 patients was complicated by multiple systemic infections occurring before, after, or concomitant with the onset of clinical neurological signs. Lethargy was noted in every patient, which progressed to stupor, coma and death in eight patients. In the other four patients, lethargy decreased with treatment but recurred and was followed by coma and death (table 4). Two patients (nos 2,3) who presented with neurological deficits demonstrated complete clinical recovery following surgical removal of the lesions and treatment with pyrimethamine $(25 \mathrm{mg} /$ day $)$ and sulfadiazine $(6-8 \mathrm{mg} /$ day) for 6 weeks. Both patients were readmitted within a month after the course of antibiotic treatment was completed because of recurrence of clinical

Table 4 Survival after onset of neurological disease

\begin{tabular}{ll}
\hline 1 month & 1 patient \\
$1-3$ months & 9 patients \\
$3-18$ months & 2 patients \\
\hline
\end{tabular}

manifestations of CNS toxoplasmosis. On CT scan, lesions in these patients were located at the sites of prior lesions and at other sites. Neither patient responded to a second course of antibiotic treatment. Two patients (nos 11, 12) responded to continuous antibiotic treatment both clinically and by resolution of lesions observed on CT. Both patients died within $11 / 2$ years from cryptococcal meningitis, sepsis, or recurrence of toxoplasmosis associated with noncompliance. Six patients (nos 1, 4, 5, 8, 10, 12) who presented without neurological signs and symptoms, deteriorated following the onset of neurological signs and symptoms, and died within 2-3 months. One patient (no 6) died subsequent to a cardiac arrest two weeks after brain biopsy. One patient (no 9) was not treated for toxoplasmosis, since the diagnosis was not made until necropsy.

\section{Discussion}

Central nervous system complications are common in AIDS patients and may be either infectious, neoplastic (CNS lymphoma), or vascular. ${ }^{4}$ In some cases, a severe encephalopathy has been found to be associated with the presence of human T-cell leucaemia (lymphotrophic) virus type III. In our series, 18 of 90 patients $(20 \%)$ either presented with or developed neurological illness. Twelve of these 18 patients harboured CNS toxoplasmosis. In the 6 remaining patients, neurologic illness was caused by cryptococcal meningitis, ${ }^{2}$ cytomegalovirus, ${ }^{2}$ and CNS lymphoma. ${ }^{2}$ In both our series and others, ${ }^{67}$ where toxoplasma was the predominant CNS pathogen, Haitians comprised the largest single group. These patients were not homosexuals, IV drug abusers, or haemophiliacs.

Clinical findings in our patients were protean. Altered or depressed mentation, seizures, cranial nerve palsies, and long tract signs were common. Patients with CNS toxoplasmosis associated with immunosuppressive therapy demonstrate a similar spectrum of neurological deficit. ${ }^{8-13}$ Focal deficits were most frequently encountered when AIDS presented solely as a neurological illness (table 2). Depressed mentation, stupor, and/or generalised seizures often were present in patients in whom systemic illness preceded or occurred concomitantly with neurologic illness.

The most frequent abnormality revealed by $C T$ in our patients with CNS toxoplasmosis were single or multiple ring-enhancing lesions. Solid modules were seen less often. Similar CT findings in AIDS patients with CNS toxoplasmosis have been noted by others. ${ }^{6}{ }^{14}$ These CT findings are in themselves nonspecific. Serum antibody studies (serum IFA, Sabin-Feldman Dye test, and toxoelisa titre) were invariably elevated. However, these studies were often negative in the CSF.

All 12 patients succumbed within $1 \frac{1}{2}$ years of diagnosis, 10 in less than 5 months. Surgical resection and 
a 6 week course of sulfadiazine and pyrimethamine was followed by multiple new lesions within 4-8 weeks in two of our patients. Toxicity to sulfadiazine was not seen. The syndrome of inappropriate secretion of antidiuretic hormone (SIADH) was diagnosed in three patients, and was presumably caused by intracerebral lesions. Accordingly, serum and urinary electrolytes should be carefully monitored in these patients. The use of long term sulfadiazine and pyrimethamine is thought to be useful in these patients. ${ }^{1516}$ This treatment resulted in remission in two of our patients until other opportunistic infections supervened.

The relentlessly progressive nature of AIDS in our small patient group is consistent with the uniform mortality noted in national surveys. ${ }^{17}$ Although brain biopsy is recommended ${ }^{2}$ to insure a correct and prompt diagnosis, neither subsequent surgical nor pharmacological intervention is effective over a 1-2 year period. This is consistent with the markedly reduced degree of cellular inflammation noted in some of our pathological specimens. Clinically silent lesions may be more therapeutically susceptible if detected earlier. Therefore early baseline cerebral CT screens of neurologically normal AIDS patients may be beneficial.

The authors thank Roger Q Cracco, MD and John Weber, PA for reviewing the manuscript, and Ms Helen R Watson for secretarial assistance.

\section{References}

${ }^{1}$ Vieira J, Frank E, Spira TJ, Landesman SH. Acquired immune deficiency in Haitians. $N$ Engl J Med 1983; 308:125-9.

${ }^{2}$ Luft BJ, Brooks RG, Conley FK, McCabe RE, Remington JS. Toxoplasma encephalitis in patients with acquired immune deficiency syndrome. JAMA 1984; 252 (7):913-7.

${ }^{3}$ Update on acquired immune deficiency syndrome (AIDS). United States Morbid Mortality Weekly Rep 1982;
31:513-4.

${ }^{4}$ Snider WD, Simpson DM, Nielsen S, Gold JWM, Metroka CE, Posner JB. Neurological complications of acquired immune deficiency syndrome: analysis of $\mathbf{5 0}$ patients. Ann Neurol 1983;14:408-13.

${ }^{5}$ Shaw GM, Harper ME, Hahn BH, Epstein LG, Gajdusek DC, Price RW. HTLV-III infections in brains of children and adults with AIDS encephalopathy. Science 1985;227:177-81.

${ }^{6}$ Post MJ, Chan JC, Hensley GT, Hoffman TA, Moskowitz LB, Lippmann S. Toxoplasma encephalitis in Haitian adults with acquired immune deficiency syndrome: a clinical pathologic-CT correlation. AJNR 1983;4: 155-62.

${ }^{7}$ Moskowitz LB, Kory P, Chan JC, Haverkos HW, Conley FK, Hemsley GT. Unusual causes of death in Haitians residing in Miami: High prevalence of opportunistic infections. JAMA 1983;250 (9):1187-91.

${ }^{8}$ Koeze TH, Klingon GH. Acquired toxoplasmosis. Arch Neurol 1964;11:191-7.

${ }^{9}$ Remington JS. Toxoplasmosis in the adult. Bull NY Acad Med 1974;50 (2):211-27.

${ }^{10}$ Townsend JJ, Wolinsky JS, Baringer JR, Johnson PC. Acquired toxoplasmosis: A neglected cause of treatable nervous system disease. Arch Neurol 1975;32:335-43.

${ }^{11}$ Schalof LA, Russell JS. Intracerebral toxoplasmosis presenting as a mass lesion. Surg Neurol 1975;4:9-11.

12 McLeod R, Berry PF, Marshall WJ, Hunt SA, Ryning FW, Remington JS. Toxoplasmosis presenting as brain abscesses: Diagnosis by computerized tomography and cytology of aspirated purulent material. Am J Med 1979;67:711-4.

${ }^{13}$ Bamford CR. Toxoplasmosis mimicking a brain abscess in an adult with treated scleroderma. Neurology (Minneap) $1975 ; 25: 343-5$.

${ }^{14}$ Alonso R, Heiman-Patterson T, Mancall EL. Cerebral toxoplasmosis in acquired immune deficiency syndrome. Arch Neurol 1984;41:321-3.

${ }^{15}$ Luft BJ, Conley F, Remington JS. Outbreak of central nervous system toxoplasmosis in Western Europe and North America. Lancet 1983;1:781-4.

${ }^{16}$ Wang B, Gold JWM, Brown AE, et al. Central-nervoussystem toxoplasmosis in homosexual men and parenteral drug abusers. Ann Int Med 1984;100:36-42.

${ }^{17}$ Update: Acquired immune deficiency syndrome (AIDS). United States Morbid Mortal Weekly Rep 1984. Vol 33, 337-9. 